\title{
Maximization of Palm Fruit Planted Area Using a Goal Programming Approach
}

\author{
Nur Jannah Md Zain', Wan Nurshazelin Wan Shahidan* \\ ${ }^{1,2}$ Faculty of Computer \& Mathematical Sciences, Universiti Teknologi Mara Cawangan Perlis, Malaysia \\ Corresponding author: *shazelin804@perlis.uitm.edu.my
}

Received Date: 31 July 2018

Accepted Date: 12 November 2018

\begin{abstract}
Malaysia is currently facing low production of palm fruit. The poor palm fruit output will inevitably affect the economy in Malaysia. Hence, the government related agency needs to find effective ways to increase the production of palm fruit. Factors that affect the production of palm fruit include palm tree planted area and quantity of the crop. This paper proposes the Goal Programming approach to maximize the production of palm fruit. The approach maximized the planted area for three rural areas and increases the number of palm fruit crop for three rural areas. This approach is used to find optimal solution to the low palm fruit output. The findings show that all the study objectives have been fully achieved. The proposed planted area available from the QM Windows 4.0 software can increase up to $75 \%$ from the existing planted area availability for three rural areas in Jengka, Pahang.
\end{abstract}

Keywords: Goal Programming, palm fruit production, optimal solution

\section{INTRODUCTION}

Paper Palm oil industry is the main commercial yield in Malaysia since 1970s (Lee, 2011). Palm oil has been chosen as new target in agriculture where there are only few scientists and producers take part in this field. The Ninth Malaysia Plan (9MP) has focused on the agriculture whereby palm oil becomes one of the primary sources to the economy of Malaysia for its vast benefits and advantages to the country.

By 2020, Malaysia is expected to lead the palm oil production since Malaysia has become the world's leader for systematizing an effective and highly productive commercial oil palm in the plantation sector. At present, it is crucial to boost the production of palm fruit due to increasing demand of palm oil in the country. In few decades, however, Malaysia has suffered from low production of palm fruit which affect the economy in Malaysia. One of the factors that affect the production of palm oil is the limited area of palm fruit plantation.

FELDA (Federal Land Development Authority) is an important government agency in Malaysia with regard to palm fruit production. There are 25 FELDA fields overall in Malaysia. Jengka field that is situated in Pahang Darul Makmur is one of the 25 FELDA fields and it is the largest FELDA field in Malaysia that produces palm oil. In addressing the limited area of palm fruit plantation, FELDA should optimize the palm fruit plantation to increase the palm oil output since the industry is still one of the biggest contributors to the country's economy.

The Goal Programming model is a method that is similar to linear programming model. The only difference is that the linear programming model managed to hold only one objective at a time while the goal programming model could have more objectives at a time. Goal programming is one of the models which have been developed to deal with multiple objectives decision-making problems (Sen and Nandi, 
2012). The increasing popularity of goal programming and its usefulness for decision-making policies has been aimed at optimizing agricultural land and other natural resources (Sen and Nandi, (2012) and Hassan et al., (2013). The goal programming approach has previously been proposed for production optimization a few times. Hassan et al. (2013) proposed goal programming approach to maximize the production of rubber and to maximize the planted areas of rubber. Leung and $\mathrm{Ng}$ (2007) used a pre-emptive goal programming model for production planning where three objectives are optimized hierarchically. Sen and Nandi (2012) proposed a goal programming approach for rubber plantation planning in 7 years by taking into consideration on the number of tree survived within the time span, expenditure and fertilizer used. Sen and Nandi (2012) used goal programming approach to set up the rubber wood manufacturing unit. Stamenkovska et al. (2014) used a weighted goal programming model for production of vegetable planning in Macedonia.

This paper is a suggestion to maximize the production of palm fruit for three different rural areas (SG Tekam, Jengka 1 and Jengka 2) in Jengka, Pahang. A goal programming model with three objectives is developed to optimize the planted area, to increase the number of crop and to increase the production of palm fruit. QM for Windows version 4.0 is used to execute this model based on data of 2015.

\section{METHODOLOGY}

In formulating the Goal Programming model, there are three important characteristics must be considered. First, Goal Programming models are all minimization problems. Second, there is no single objective but multiple goals to be achieved. Third, deviations of high priority goals must be minimized to the highest possible before the next highest priority goals are considered.

\section{Goals}

There are three goals to achieve. The goals will be ranked in order of importance. The first goal is to increase the planted areas (hectares) for three rural areas in Pahang (SG Tekam, Jengka 1, Jengka 2) by maximizing each of the palm fruit planted areas. The total area is aimed to reach 725 hectare. The target to maximize the planted areas is based on the availability of land in Jengka, Pahang where there is only 1450 hectares. Therefore the target is $50 \%$ from the availability of the total area. There will be no decrement in each of the planted area. The second goal is to increase the number of crop up to 350000 based on the increasing number in the planted area.

The third goal is to maximize the productivity of palm fruit for three rural areas by increasing the production up to $50 \%$. Table 1 summarized the data set used in this paper from the three rural areas in Pahang. There will be no decrement in each of the planted area. However, because of the difficulty on acquiring data, the scope of this paper is limited to increase the planted area without covering the economic perspective.

Table 1: Planted areas, number of crop and production of palm fruit

\begin{tabular}{cccccc}
\hline Factors & SG Tekam & Jengka 1 & Jengka 2 & Total & $\begin{array}{c}\text { Total Targets } \\
\text { (Up to 50\%) }\end{array}$ \\
\hline $\begin{array}{c}\text { Production of palm fruit } \\
\text { (in tonnes) }\end{array}$ & 15342.6 & 3178.4 & 12321.8 & 30842.8 & 46264.3 \\
$\begin{array}{c}\text { Planted area } \\
\text { (hectares) }\end{array}$ & 805.62 & 253.76 & 617.82 & $\begin{array}{c}1677.2 \\
\text { (used area) } \\
1450\end{array}$ & 2402.2 \\
& 750 & 200 & 500 & (available area)
\end{tabular}




\section{Ranking goals with priority}

The first goal will be more important than the second goal which in turn will be more important than the third. Priorities are signed to each deviational variable. Therefore, set of priority depends on the importance level of each goal. All the goals will be achieved only when the goal in priority 1 is achieved. In brief, planted area is the most important goal to achieve, followed by the second important goal which is number of crop and finally the third goal which is the production of palm fruits as shown in Table 2 .

Table 2: Goals with priority

\begin{tabular}{lc}
\hline \multicolumn{1}{c}{ Goals } & Priority (P) \\
\hline Planted area (hectares) & $P_{1}$ \\
Number of crop & $P_{2}$ \\
Production of palm fruit (in tonnes) & $P_{3}$ \\
\hline
\end{tabular}

Completed data from the Goal Programming model for total of the three rural areas are as shown below. With priority and the ranking of goals considered, the Goal Programming model is as follows:

\section{CONSTRAINTS}

$$
\begin{aligned}
& 805.62 x_{1}+d_{1}^{-}-d_{1}^{+}=750 \\
& 253.76 x_{2}+d_{2}^{-}-d_{2}^{+}=200 \\
& 617.82 x_{2}+d_{2}^{-}-d_{2}^{+}=500 \\
& \text { Minimize }=P_{1} d_{1}^{-}+P_{2} d_{2}^{-}+P_{2} d_{a}^{-}
\end{aligned}
$$

Subject to:

(Planted areas for each area)

$$
\begin{aligned}
& 805.62 x_{1}+d_{1}^{-}-d_{1}^{+}=1180.62 \\
& 253.76 x_{2}+d_{2}^{-}-d_{2}^{+}=353.7 \\
& 617.82 x_{2}+d_{a}^{-}-d_{a}^{+}=867.82
\end{aligned}
$$

(Number of crops for each area)

$$
\begin{aligned}
& 106342 x_{1}+d_{1}^{-}-d_{1}^{+}=15951 \\
& 34258 x_{2}+d_{2}^{-}-d_{2}^{+}=5138 \\
& 84024 x_{a}+d_{a}^{-}-d_{a}^{+}=12603
\end{aligned}
$$

(Production of palm fruit for each area)

$15342.6 x_{1}+d_{1}^{-}-d_{1}^{+}=23013$.

$3178.4 x_{2}+d_{2}^{-}-d_{2}^{+}=4767.6$

$12321.8 x_{\mathrm{a}}+d_{\mathrm{a}}^{-}-d_{\mathrm{a}}^{+}=18482.7$

Where

$x_{1}=$ SG Tekam

$x_{2}=$ Jengka 1

$x_{\mathrm{g}}=$ Jengka 2 
$d_{1}^{-}=$underachievement of the planted areas target

$d_{1}^{+}=$overachievement of the planted areas target

$d_{2}^{-}=$underachievement in the number of the palm crop target

$d_{2}^{+}=$overachievement in the number of the palm crop target

$d_{a}^{-}=$underachievement the production palm fruit goals

$d_{a}^{+}=$overachievement the production palm fruit goals

\section{RESULTS AND DISCUSSIONS}

Table 3 below shows the analysis for each goal. The results in QM for window's shows 0 values for nonachievement which means the result is achieved and $d+$ values is 0 meaning that the target has been fully utilized. Positive deviation $(\mathrm{d}+)$ for the planted area for SG Tekam, Jengka 1 and Jengka 2 with respective values 27.81 acres, 26.88 acres and 58.91 acres means the area have exceeded the target area for each rural area.

Table 3: Goals analysis from the deviation

\begin{tabular}{ccccc}
\hline Goal & Area & $\begin{array}{c}\text { Non- } \\
\text { achievement }\end{array}$ & $\begin{array}{c}\text { More } \\
\text { achievement } \\
\mathbf{d +}\end{array}$ & $\begin{array}{c}\text { Less } \\
\text { achievement } \\
\mathbf{d}-\end{array}$ \\
\hline \multirow{3}{*}{ Planted area } & SG Tekam & 0 & 27.81 & 0 \\
& Jengka 1 & 0 & 26.88 & 0 \\
& Jengka 2 & 0 & 58.91 & 0 \\
\hline \multirow{3}{*}{ Number of crop } & SG Tekam & 0 & 0 & 0 \\
& Jengka 1 & 0 & 0 & 0 \\
\hline \multirow{2}{*}{ Production of } & Jengka 2 & 0 & 0 & 0 \\
palm fruit & SG Tekam & 0 & 0 & 0 \\
& Jengka 1 & 0 & 0 & 0 \\
\hline
\end{tabular}

This results show that when the first priority for each three rural area is achieved, the target for the number of crop for each three rural areas will be achieved and at the same time the production of palm fruit will be achieved. Meaning the planted area is the main factor to increase the production of palm fruit followed by the number of crops.

Table 4 below shows the result of constraint analysis. The result suggested that the planted area can be increased at maximum value. The current planted areas in 2015 and the result that has been running in the QM Windows software shows that the size of planted area can also be maximized for year 2016. The finding shows that the target to increase the planted area up to $50 \%$ from its original area availability has been achieved based on suggestion from QM Windows.

Table 4: Constraint analysis from deviation

\begin{tabular}{ccccc}
\hline Constraint & $\begin{array}{c}\text { Achievement in } \\
\mathbf{2 0 1 5}\end{array}$ & $\begin{array}{c}\text { Suggested in } \\
\mathbf{2 0 1 6}\end{array}$ & $\begin{array}{c}\text { More } \\
\text { achievement } \\
\mathbf{d +}\end{array}$ & $\begin{array}{c}\text { Less } \\
\text { achievement } \\
\text { d- }\end{array}$ \\
\hline $\begin{array}{c}\text { Planted area } \\
\text { SG Tekam }\end{array}$ & 805.62 & 1264.05 & 458.43 & 0 \\
$\begin{array}{c}\text { Planted area } \\
\text { Jengka 1 }\end{array}$ & 253.76 & 434.4 & 180.64 & 0
\end{tabular}




\begin{tabular}{|c|c|c|c|c|}
\hline Planted area & 617.82 & 1044.55 & 426.73 & 0 \\
\hline
\end{tabular}

Table 5 shows that the comparison between the targets for planted area for three rural areas for 2016 and the suggested planted areas for three rural areas in 2016 by using QM for Windows software. The target of planted area for three rural areas is calculated manually without using any software.

Table 5: Target and Suggested (result) in 2016

\begin{tabular}{cccccc}
\hline $\begin{array}{c}\text { Planted area } \\
\text { (acres) }\end{array}$ & Availability & $\begin{array}{c}\text { Current } \\
\text { used }\end{array}$ & $\begin{array}{c}\text { Increment } \\
\text { by 50\% }\end{array}$ & Total target & $\begin{array}{c}\text { Suggested based } \\
\text { on QM Window }\end{array}$ \\
\cline { 2 - 6 } & & $\begin{array}{c}\text { Planted area can } \\
\text { maximize up to: }\end{array}$ \\
\hline SG Tekam & 750 & 805.62 & 375 & 1180.62 & 458.43 \\
Jengka 1 & 200 & 253.76 & 100 & 353.76 & 180.64 \\
Jengka 2 & 500 & 617.82 & 250 & 867.82 & 426.73 \\
Total & 1450 & 1677.2 & 725 & 2402.2 & 1065.8 \\
\hline
\end{tabular}

With reference to manual calculation for three rural areas, the total target is 2402.2 acres from the year 2015 whereby the used planted area used is 1677.2 acres. The target is 50\% (725 acres) from the availability of planted area (1450 acres). The result in QM Window's however shows that the planted area can be maximized up to 1065.8 acres from the availability of planted area. The difference shows an increment of 340.8 acres. The result shows that this study has achieved its objective to increase the production of palm fruit for each three rural areas in Jengka, Pahang. The objective is achieved first by increasing the planted areas. Followed by the number of crop and planted area for each three rural areas in Jengka, Pahang. This study shows that when the first priority for the goal is successfully achieved, other goals will also be achieved for the second and third priority. Meaning the first priority should be accomplished first. The priorities are all realized in sequence. The target to increase the planted area up to $50 \%$ from the availability of its planted area in Jengka, Pahang was successfully attained. In fact, results from QM Windows suggested that the planted area can be increased up to $75 \%$.

\section{CONCLUSION AND RECOMMENDATION}

This paper signifies that the goal programming approach can be applied in agriculture and various fields as solution to problems often faced by farmers and producers. The model was formulated based on the availability of the three rural areas in Jengka Pahang. In short, all the three study objectives have been successfully achieved. The goal programming approach can be proposed for larger scale production areas which are more than 750 acres. A number of important advances have also been made in the area of goal programming. Therefore, for the extension of this study, a number of approaches like fuzzy goal programming, integer goal programming, decomposition goal programming, nonlinear goal programming and interval goal programming can also be considered.

\section{REFERENCES}

Hassan, N.,Pazil, M. A. H., Idris, S. \& Razman, N. F. (2013).The goal programming model for bakery production. Advances in Environmental Biology, 9, 187-190. 
Hassan, N., Mohamed Hamzah, H. H., \& Zain, M. S. M. (2013). A goal programming approach for rubber production in Malaysia. American Eurasian Journal of Sustainable Agriculture, 11, $50-53$.

Lee, Y. N. (2011). Increase Malaysia Palm Oil Production efficiency. Degree of Master of Philosophy in System Dynamics, University of Bergen, Norway.

Leung S.C.H. \& W.I. Ng, 2007.A goal programming model for production planning of perishable products with postponement. Computers \& Industrial Engineering, 53(3): 531-541.

Sen N. \& M. Nandi, 2012. A Goal Programming Approach to Rubber Plantation Planning in Tripura. Applied Mathematical Sciences, 6(124): 6171-6179.

Sen, N. \& M. Nandi, 2012. Goal Programming, its Application in Management Sectors-Special Attention into Plantation Management: A Review. International Journal of Scientific and Research Publications, 2(9): 1-6.

Stamenkovska, I. J., Stojceska, A. M., Dimitrievski, D., Erjavec, E., \& Žgajnar, J. (2014). A weighted goal programming model for vegetable production planning in Republic of Macedonia. The Australian Journal of Agricultural Economics, 26, 114-130. 